\title{
Efisiensi Pemasaran Jagung Tongkol (Zea mays, L.) di Kabupaten Indramayu
}

\author{
Ayu Lestari ${ }^{1}$, Wiwik Ambarsari ${ }^{2}$ Fadhillah Laila $^{3}$ \\ 1,2,3 Program Studi Agribisnis, Fakultas Pertanian, Universitas Wiralodra \\ Email: ayulestari001.al@gmail1..com, wiwikambarsari@yahoo.co.id², fadhillahlaila@gmail.com³
}

\begin{abstract}
ABSTRAK
Permintaan jagung tongkol di Kabupaten Indramayu masih dipenuhi dari luar daerah yang mempengaruhi harga di tingkat produsen dan konsumen. Penelitian ini bertujuan untuk mengetahui besarnya nilai elastisitas transmisi harga dan efisiensi pemasaran jagung tongkol di Kabupaten Indramayu. Penelitian ini dilakukan pada bulan November 2018 sampai dengan Agustus 2019. Metode yang digunakan adalah deskriptif kuantitatif. Desain dengan pendekatan kausal komparatif, pada model ekonometrika yang menggunakan data time series harga bulanan jagung di tingkat produsen dan harga bulanan jagung di tingkat konsumen dari Januari 2013 sampai Desember 2017. Analisis efisiensi pemasaran ini menggunakan persamaan regresi berbasis OLS (Ordinary Least Square) yang difungsikan pada aplikasi SPSS versi 21. Hasil penelitian menunjukkan bahwa besarnya nilai elastisitas transmisi harga sebesar 0,944 dan pemasaran jagung tongkol tidak efisien di Kabupaten Indramayu.
\end{abstract}

Kata Kunci : efisiensi pemasaran, elastisitas transmisi harga, jagung tongkol

\section{I.Pendahuluan}

Pembangunan di sektor pertanian hingga kini tetap menjadi prioritas pembangunan. Tujuan pembangunan pertanian adalah untuk meningkatkan produksi guna memenuhi kebutuhan pangan, meningkatkan pendapatan petani, memperluas kesempatan kerja serta mendorong pemerataan kesempatan berusaha. Sehingga sektor pertanian diharapkan menjadi basis pertumbuhan ekonomi di masa yang akan datang (Suharjito, 2011 dalam Azria, 2017).

Salah satu komoditi andalan di sektor pertanian adalah jagung. Penetapan jagung sebagai komoditas andalan dan program unggulan padi jagung kedelai (pajale) karena manfaatnya yang serba guna. Jagung bermanfaat sebagai pangan nasional karena merupakan makanan pokok utama setelah beras, di samping sebagai bahan makanan pokok di Indonesia, jagung telah menjadi lebih sangat penting karena merupakan bahan pokok bagi industri pakan ternak (Suharjito, 2011 dalam Azria, 2017). Jagung menempati posisi kunci sebagai salah satu sereal paling penting untuk konsumsi manusia dan ternak, tidak hanya dalam bentuk produk makanan namun juga produk turunan lainnya (Idris dan Ali, 2015 dalam Sondakh et al., 2016). 
Kabupaten Indramayu pada tahun 2015 jagung menduduki peringkat kedua produksi tanaman pangan tertinggi dengan produksi 709,93 ton, kemudian di tingkat pertama di duduki oleh padi sebanyak 1.465.740,60 ton. Pada tahun 2016 jagung menduduki peringkat pertama tanaman palawija dengan produksi $107.335,30$ ton (Badan Pusat Statistik Kabupaten Indramayu Tahun 2016-2017). Efisiensi kegiatan distribusi komoditas pertanian juga dipengaruhi oleh panjang pendeknya mata rantai jalur distribusi. Besarnya margin keuntungan yang ditetapkan oleh setiap mata rantai tersebut dan gejala rendahnya harga yang diterima petani erat kaitannya dengan keadaan pasar yang tidak efisien. Maka semakin pendek mata rantai distribusi dan semakin kecil margin keuntungan yang ditetapkan, maka kegiatan distribusi tersebut semakin efisien. Hal ini sering ditunjukkan dengan gejala terlalu besarnya marjin pemasaran dan struktur pasar yang bersaing kurang sempurna (Widiastuti dan Harisudin, 2013).

Persentase harga yang diterima oleh petani dari harga yang dibayarkan oleh konsumen kecil. Salah satu faktor yang menyebabkan masalah tersebut adalah lemahnya posisi petani di dalam pasar. Hal ini sangat merugikan para petani dan juga masyarakat konsumen, harga yang rendah di tingkat petani akan menyebabkan menurunnya minat petani untuk meningkatkan produksinya dan harga yang tinggi di tingkat konsumen menyebabkan konsumen akan mengurangi konsumsi (Abdi, 2018). Berdasarkan latar belakang permasalahan yang terjadi dalam proses pemasaran jagung sangatlah menarik untuk dibahas terutama pemenuhan produksi jagung di Indramayu masih mengandalkan impor dari luar daerah. Oleh karena itu, perlu dilakukan penelitian mengenai efisiensi pemasaran jagung tongkol yang diamati dari nilai elastisitas transmisi harga. Data yang diambil berupa data harga jagung tongkol di tingkat konsumen dan di tingkat produsen yang berasal dari Badan Pusat Statistik Kabupaten Indramayu Tahun 2014 - 2018 (Lampiran 5). Adapun judul penelitian ini adalah Efisiensi Pemasaran Jagung Tongkol (Zea mays, L.) di Kabupaten Indramayu Tahun 2013-2017.

\section{Metode Penelitian}

Objek penelitian ini adalah data sekunder yaitu data Time Series bulanan harga produsen dan harga konsumen komoditas jagung di Kabupaten Indramayu. Metode penelitian ini adalah penelitian deskriptif kuantitatif secara komparatif untuk menjawab secara mendasar tentang sebab-akibat dengan menganalisis faktor-faktor penyebab terjadinya ataupun munculnya satu fenomena tertentu (Nazir, 2011).

Desain dalam penelitian ini adalah Kausal Komparatif (causal comparative research) yang ditujukan untuk menyelidiki kemungkinan hubungan sebab akibat berdasarkan pengamatan terhadap akibat yang ada dan mencari kembali faktor yang mungkin menjadi penyebab melalui data tertentu, ciri-ciri pokok dalam penelitian ini adalah bersifat ex-pos-facto yaitu data dikumpulkan setelah semua kejadian yang dipersoalkan telah berlangsung (Nazir, 2011).

\section{Analisis Data}

Data jagung tongkol yang diperoleh terlebih dahulu dilakukan analisis asumsi klasik untuk mengetahui keabsahan uji data sesuai syarat statistik yang harus dipenuhi pada analisis regresi berbasis OLS (Ordinary Least Square) (Lampiran 7), yaitu Normalitas Data, Autokorelasi, Multikolinieritas, dan Heterokedastisitas sehingga data tersebut normal. Setelah dilakukan uji asumsi klasik yang telah memenuhi persyaratan statistik maka analisis regresi akan diperoleh nilai elastisitas transmisi harga dari koefisien $\left(\beta_{1}\right)$, kemudian besarnya nilai elastisitas transmisi harga tersebut menunjukan efisien atau tidak efisien dalam pemasaran. Adapun tahapan analisis data dalam penelitian ini dapat dijelaskan sebagai berikut : 


\section{1) Uji Asumsi Klasik dalam Regresi}

Data time-series biasanya terjadi autokorelasi pada antar variabel perlu ada perbaikan dengan melakukan transformasi data yang menunjukkan adanya autokorelasi. Autokorelasi antar anggota serangkaian observasi yang diurutkan waktu (Gujarati, 2012). Autokorelasi terjadi atau tidak terjadi dapat diketahui dengan analisis menggunakan SPSS versi 21. Adapun pengujian menurut Gujarati (2012) dapat dilihat pula pada Gambar 2. 29 Gambar 2. Posisi Koefisien D-W (Sumber : Gujarati, 2012) Keterangan : Ho : Tidak ada korelasi positif, jika : d $<\mathrm{dl}$ : Menolak $\mathrm{H}_{0} \mathrm{~d}>\mathrm{du}$ : Tidak menolak $\mathrm{H}_{0} \mathrm{dl} \leq \mathrm{d} \leq \mathrm{du}$ : pengujian tidak meyakinkan $\mathrm{H}_{0}$ : tidak ada autokorelasi negatif, jika d $>4-\mathrm{dl}$ : menolak $\mathrm{H}_{0} \mathrm{~d}<4-\mathrm{du}$ : terima $\mathrm{H}_{0} 4-\mathrm{du} \leq \mathrm{d} \leq$ 4 - dl : pengujian tidak meyakinkan Keterangan : d : Durbin Watson dl : Durbin Lower ( Batas bawah) du : Durbin Upper (Batas atas) Gujarati (2012) menjelaskan bahwa jika persamaan regresi terjadi auokorelasi maka harus adanya perbaikan untuk model regresi sehingga tidak terjadi autokorelasi, salah satu perbaikannya ialah dengan jalan menghitung $\rho$ $=$ perkiraan $\rho$ (dengan asumsi hanya terjadi otoregresif order pertama) dengan pergunakan untuk mentransformasikan data asli, seperti halnya mencari persamaan selisih umum (Generalized Difference Equation). Transformasi 30 perbedaan pertama yang disajikan tadi sangat populer dalam ekonometrika terapan karena mudah untuk dilaksanakan.

Oleh karena itu jika $d$ sudah diketahui, maka menggunakan teknik Theil-Negar untuk memperoleh perkiraan $\rho$ (Gujarati, 2012) sebagai berikut :

$\rho=1-d 2$

setelah dilakukan perhitungan dengan menggunakan rumus dapat diperoleh nilai $\rho$. Setelah itu data sekunder yang sudah di Ln akan ditransformasikan dengan menggunakan taksiran dapat mentransformasikan data sebagai berikut :

$(\mathrm{LnHp}-\rho \mathrm{LnHpt-1})$ dan $\left(\mathrm{LnHK}_{n}-\rho \mathrm{LnHk}_{\mathrm{t}=1}\right)$

Nilai pertama untuk LnHP dan LnHK adalah dengan mentransformasikan data Gujarati (2012) sebagai berikut :

$\sqrt{ }\left(1-\rho_{2}\right) \operatorname{LnH} p_{1}$ dan $\sqrt{ }\left(1-\rho_{2}\right) L n H k_{1}$

Setelah data ditransformasikan, dapat dilakukan analisis persamaan regresi kembali untuk menghasilkan persamaan regresi yang baik dan tidak terjadi gangguan asumsi klasik antar variabel (normalitas data, multikolinieritas, autokorelasi dan heterokedastisitas).

\section{2) Analisis Elastisitas Transmisi Harga}

Efisiensi pemasaran Jagung dalam penelitian ini dapat diketahui dengan menggunakan analisis elastisitas transmisi harga. Rumus transmisi harga menurut Gujarati (2012) sebagai berikut :

$\mathrm{P}_{f}=\beta_{0}+\operatorname{Pr} \beta 1 \mathrm{e}$

Kemudian ditransformasikan dalam bentuk linear menjadi :

$\mathrm{L}_{n} \mathrm{P}_{\mathrm{f}}=\mathrm{L} \beta_{0}+\beta_{1} \mathrm{LnP}_{\mathrm{r}}+\mathrm{e}$ 
Keterangan :

$\beta_{0}:$ Intersip

$\beta_{1}:$ Koefisien elastis

$\mathrm{Pr}_{\mathrm{r}}$ : Harga rata-rata bulanan di tingkat konsumen

$\mathrm{P}_{\mathrm{f}}$ : Harga rata-rata bulanan di tingkat produsen (petani)

e : Gangguan stokhastik atas kesalahan (disturbance term)

Perhitungan dapat dipermudah dengan menggunakan rumus sebagai berikut :

$\mathrm{L}_{n} \mathrm{HP}=\mathrm{Ln}_{n} \beta_{0}+\beta_{1} \mathrm{LnHK}_{n}+\mathrm{e}$

Keterangan :

$\beta_{0}:$ Intersip

$\mathrm{C}:$ Koefisien elastis

$\mathrm{HK}$ : Harga rata-rata bulanan di tingkat konsumen (Rp)

$\mathrm{HP}$ : Harga rata-rata bulanan di tingkat produsen (petani) $(\mathrm{Rp})$

e : Gangguan stokhastik atas kesalahan (disturbance term)

\section{3) Efisiensi Pemasaran}

Efisiensi pemasaran diperoleh dari hasil analisis regresi pada nilai elastisitas transmisi harga (Et) dari koefisien $\left(\beta_{0}\right)$. Jika nilai Et $>1$, menunjukkan bahwa persentase kenaikan harga di tingkat konsumen lebih tinggi dibandingkan di tingkat produsen. Jika nilai Et $<1$, maka persentase kenaikan harga ditingkat konsumen lebih rendah dibandingkan di tingkat produsen, sehingga dapat disimpulkan bahwa keadaan pasar mencerminkan pasar persaingan yang tidak sempurna dan pemasaran suatu komoditi dikatakan tidak efisien. Jika nilai Et $=1$ 32 maka persentase perubahan harga di tingkat konsumen mengakibatkan perubahan harga di tingkat produsen dengan persentase yang sama perubahan sebesar $1 \%$ di tingkat produsen akan dikuti dengan perubahan harga di tingkat konsumen sebesar 1\%. Hal ini dapat disimpulkan bahwa keadaan pasar mencerminkan pasar persaingan yang sempurna dan pemasaran suatu komoditas dikatakan efisien (Rahim dan Hastuti, 2005).

\section{III.Hasil dan Pembahasan \\ Keadaan Geografis dan Topografi}

Secara geografis Kabupaten Indramayu beriklim tropis (sedang) yang terletak pada $107^{0} 52^{\prime}$ $108^{0} 36^{\prime}$ Bujur Timur dan $6^{0} 15^{\prime}-6^{0} 40^{\prime}$ Lintang Selatan topografinya sebagian besar merupakan dataran atau daerah landai dengan kemiringan tanahnya rata-rata $0-2 \%$. Keadaan ini berpengaruh terhadap drainase, bila curah hujan cukup tinggi, maka di daerah- daerah tertentu akan terjadi genangan air (Badan Pusat statistik Kabupaten Indramayu, 2018). Menurut Zulfahmi (2012) bahwa tanaman jagung tongkol dapat tumbuh di daerah-daerah beriklim sedang hingga daerah beriklim subtrapis/tropis yang basah yang terletak antara $0^{0}-5^{0}$ Lintang Utara hingga $0^{0}-40^{\circ}$ Lintang Selatan sedangkan topografi yang baik untuk tanaman jagung tongkol $0-8 \%$ sehingga sesuai dengan geografis dan topografi di Kabupaten Indramayu.

\section{Iklim}

Letak Kabupaten Indramayu yang membentang sepanjang pesisir pantai utara Pulau Jawa membuat suhu udara di kabupaten ini cukup tinggi, yaitu berkisar antara $22,9^{\circ}-30^{\circ}$ Celcius. Sementara rata-rata curah hujan sepanjang tahun 2017 adalah sebesar $1.683 \mathrm{~mm}$ dengan jumlah hari hujan 104 hari. Menurut Zulfahmi (2012) suhu ideal yang sesuai untuk tanaman jagung antara $23^{\circ}-$ $27^{\circ} \mathrm{C}$ dengan rata-rata curah hujan ideal sekitar $85-200 \mathrm{~mm} /$ bulan atau sekitar $1.020 \mathrm{~mm} /$ tahun sesuai dengan iklim dan curah hujan di Kabupaten Indramayu. Adapun curah hujan tertinggi terjadi di 
Kecamatan Patrol kurang lebih sebesar $6.792 \mathrm{~mm}$ dengan jumlah hari hujan tercatat 85 hari, sedang curah hujan terendah terjadi di Kecamatan Terisi kurang lebih sebesar $1.059 \mathrm{~mm}$ dengan jumlah hari hujan tercatat 79 hari (Badan Pusat Statistik Kabupaten Indramayu, 2018).

\section{Pertanian}

Kabupaten Indramayu terdiri dari beberapa subsektor pertanian diantaranya adalah tanaman pangan, peternakan, perikanan, perkebunan, hortikultura dan kehutanan. Bidang- bidang tersebut menjadi sumber mata pencaharian mayoritas penduduknya dan merupakan sumber pemasukan produk domestik regional bruto (Badan Pusat Statistik Kabupaten Indramayu, 2018).

Tanaman pangan terdiri dari jenis padi-padian (serelia), umbi-umbian, dan kacang- kacangan. Data tanaman pangan (Padi, Jagung, Kedelai) di Indramayu pada tahun 2017 produksi padi, jagung dan kedelai mengalami penurunan dari tahun sebelumnya, hal ini juga berpengaruh pada tingkat produktivitasnya yang juga mengalami penurunan. Keberhasilan produksi jagung tidak memberikan dampak yang berarti bila tidak diimbangi dengan peningkatkan pendapatan petani. Pendapatan petani dipengaruhi oleh produktivitas usahatani jagung dan harga dari komoditas jagung yang dihasilkan. Sementara harga jagung yang diterima petani dipengaruhi oleh efisiensi pemasaran jagung yang dihasilkan, sehingga perbedaan harga jagung yang diterima produsen dan konsumen memiliki rentang yang cukup lebar menandakan masih belum efisiensinya pemasaran jagung yang terjadi (Restiana, 2010).

\section{Rata-rata Harga Jagung di Kabupaten Indramayu}

Rata-rata harga jagung tongkol di tingkat produsen dan konsumen di Kabupaten Indramayu pada Tahun 2013-2017 dapat dilihat pada Tabel 1 pada tingkat produsen cenderung meningkat setiap tahunnya. Rata-rata harga jagung tongkol pada tingkat konsumen di Kabupaten Indramayu mengalami fluktuatif dikarenakan daya beli rendah sehingga harga produk pertanian yang tidak menentu. Menurut Purwanto (2009) bahwa produk pertanian dipengaruhi oleh sifat komoditas pertanian yang mudah busuk, mudah rusak dan bersifat musiman terutama oleh kondisi iklim sehingga produksi menjadi tidak terjamin apalagi jagung tongkol di Kabupaten Indramayu bukan sebagai makanan pokok.

Berdasarkan Tabel 1, pada tahun 2013 sampai tahun 2016 menunjukkan penurunan harga di tingkat konsumen yang disebabkan penawaran tinggi sehingga harga turun. Sedangkan pada tahun 2017 rata-rata harga jagung tongkol menunjukkan kenaikan harga di tingkat produsen dan konsumen merupakan inflasi karena meningkatnya permintaan atau menurunnya produksi. Menurut Sukirno (1998) bahwa inflasi merupakan suatu proses kenaikan harga-harga yang berlaku secara umum dalam suatu perekonomian.

Tabel 1. Rata-rata Harga Jagung Tongkol di Tingkat Produsen dan Konsumen dari Tahun 20132017.

\begin{tabular}{ccc}
\hline \multirow{2}{*}{ Tahun } & \multicolumn{3}{c}{ Rata-rata Harga } \\
\cline { 2 - 3 } & Produsen $(\mathrm{Rp} / \mathrm{Kg})$ & Konsumen $(\mathrm{Rp} / \mathrm{Kg})$ \\
\hline 2013 & 1.822 & 1.822 \\
2014 & 1.960 & 1.960 \\
2015 & 2.683 & 2.683 \\
2016 & 2.783 & 2.783 \\
2017 & 3.146 & 3.146 \\
\hline
\end{tabular}

Sumber : Badan Pusat Statistik Kabupaten Indramayu Tahun 2013-2017, diolah Tahun 2018

Rata-rata harga jagung tongkol di tingkat produsen pertahunnya mengalami kenaikan, sedangkan rata-rata harga jagung tongkol di tingkat konsumen mengalami fluktuasi harga pertahunnya. Kenaikan harga jagung tongkol pada tingkat konsumen Rp 958 (31,49\%) dialami pada tahun 2013 ke tahun 2014. Tahun 2015 ke tahun 2016 mengalami penurunan harga jagung tongkol Rp $42(1,18 \%)$ di tingkat konsumen dan pada tahun 2017 jagung tongkol mengalami kenaikan harga kembali dari tahun 2016 sebesar Rp 485 (11,45\%). Rata- rata harga jagung tongkol di tingkat konsumen disebabkan karena terjadi inflasi yaitu menurunnya produksi atau meningkatnya produksi 
sehingga terjadi peningkatan permintaan menyebabkan harga konsumen naik sesuai dengan definisi dari Sukirno (1998). Lebih jelasnya mengenai rata-rata harga jagung tongkol di tingkat produsen dan konsumen dapat dilihat grafik pada Gambar 1.

Harga Rata-rata Jagung Tongkol Per Tahun

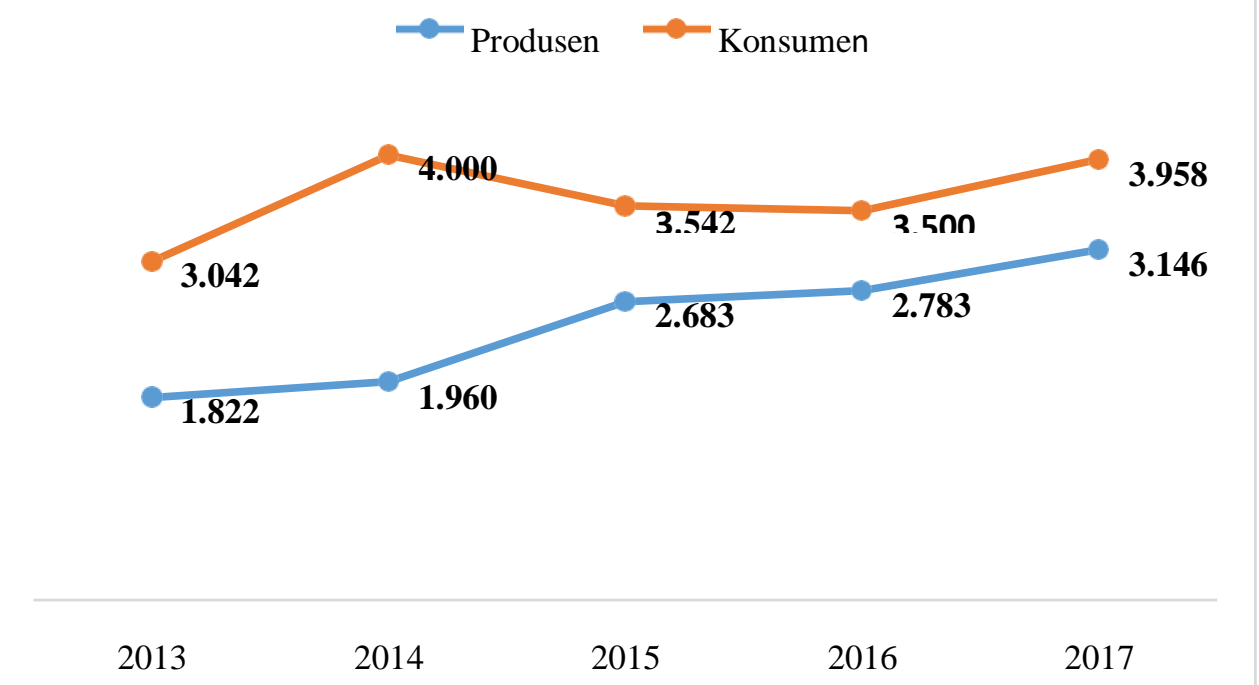

Gambar 1. Grafik Rata-rata Harga Jagung Tongkol di Tingkat Produsen dan Konsumen di Kabupaten Indramayu

\section{Uji Asumsi Klasik}

Menurut Gujarati (2012) bahwa uji asumsi klasik adalah persyaratan statistik yang harus dipenuhi pada analisis regresi yang berbasis Ordinary Least Square (OLS), menjelaskan beberapa asumsi klasik adalah sebagai berikut :

1. nilai rata-rata bersyarat dari unsur gangguan populasi $e_{i}$ tergantung dari nilai tertentu variabel menjelaskan $(\mathrm{X})$ adalah 0

2. Variasi bersyarat dari $e_{i}$ adalah konstan atau homokedastisitas.

3. Tidak ada autokorelasi dalam gangguan

4. Variabel yang menjelaskan adalah nonstokastik (tetap dalam penyampelan berulang) atau, jika stokastik, didistribusikan secara independen dari gangguan.

5. $\quad e$ didistribusikan secara normal dengan rata-rata data varians yang diberikan pada asumsi 1 dan 2.

\section{Multikolinieritas}

Asumsi dalam model OLS adalah tidak adanya hubungan linier antara variabel independent (harga konsumen), apabila terjadi hubungan maka terjadi multikolinieritas. Hubungan linier antara variabel independent dapat terjadi dalam bentuk hubungan linier yang sempurna (perfect) maupun hubungan linier yang kurang sempurna (imperfect). Gejala multikolinieritas dapat dilihat dari Collinearity Statistics hasil VIF dan tolerane lebih besar dari satu menunjukkan adanya gejala mulltikolinieritas, sedangkan nilai VIF dan tolerance yang mendekati satu menunjukkan tidak adanya gejala multikolinieritas.

Tabel 2. Nilai Koefisien Regresi dan Nilai VIF Ln Harga Produsen dan Konsumen Jagung di Kabupaten Indramayu tahun 2013-2017.

Coefficients $^{\mathrm{a}}$

\begin{tabular}{|c|c|c|c|c|c|c|c|c|}
\hline \multirow{2}{*}{\multicolumn{2}{|c|}{ Model }} & \multicolumn{2}{|c|}{ Unstandardized Coefficients } & \multirow{2}{*}{$\begin{array}{c}\text { Standardized } \\
\text { Coefficients } \\
\text { Beta } \\
\end{array}$} & \multirow{2}{*}{$\mathrm{t}$} & \multirow{2}{*}{ Sig. } & \multicolumn{2}{|c|}{ Collinearity Statistics } \\
\hline & & B & Std. Error & & & & Tolerance & VIF \\
\hline \multirow{2}{*}{1} & ,006 & ,026 & ,026 & & ,239 & & & \\
\hline & ,944 & ,944 & ,040 & 952 & 23,707 & & 1,000 & 1,000 \\
\hline
\end{tabular}


Keterangan : a. Dependent Variable: Ln_Hp

Hasil output SPSS versi 21 sudah menunjukkan tidak terdapat multikolinieritas pada hasil kedua pada Tabel 2, yaitu nilai VIF sebesar 1 dan nilai tolerance sebesar 1 yang menunjukkan bahwa tidak terdapat multikolinieritas pada data tersebut.

\section{Autokorelasi}

Asumsi pada regresi dimana variabel dependen tidak terjadi autokorelasi dengan menggunakan Uji Durbin-Watson (DW). Uji ini menghasilkan nilai DW hitung $(d)$ dan nilai DW Tabel $(d l \& d u)$. Hasil dari analisis regresi pada Tabel 3 nilai DW hitung $(d)$ sebesar 0,132 lebih kecil dari nilai $d l=1,514$ dan $d u=1,651$ yaitu menunjukkan adanya autokorelasi positif (terjadi autokorelasi). Data time series sering terjadi autokorelasi, menurut Mubyarto (1989) mengemukakan bahwa terjadinya jarak waktu yang lebar antara pengeluaran dan penerimaan dalam pertanian mengakibatkan perbedaan yang jelas antara persoalan-persoalan ekonomi pertanian dan persoalan di luar bidang pertanian, jarak waktu ini sering pula disebut gestation periodi.

Tabel 3. Nilai Koefisien Regresi Transformasi Harga Produsen dan Konsumen di Kabupaten Indramayu Tahun 2013-2017.

\section{Model Summaryb}

\begin{tabular}{|c|c|c|c|c|c|c|c|c|c|c|}
\hline \multirow[b]{2}{*}{ Model } & \multirow[b]{2}{*}{$\mathrm{R}$} & \multirow{2}{*}{$\begin{array}{c}\mathrm{R} \\
\text { Square }\end{array}$} & \multirow[b]{2}{*}{$\begin{array}{c}\text { Adjusted } \\
\text { R } \\
\text { Square }\end{array}$} & \multirow{2}{*}{$\begin{array}{c}\text { Std. } \\
\text { Error of } \\
\text { The } \\
\text { Estimate }\end{array}$} & \multicolumn{5}{|c|}{ Change Statistics } & \multirow[b]{2}{*}{$\begin{array}{l}\text { Durbin } \\
\text { Watson }\end{array}$} \\
\hline & & & & & $\begin{array}{c}\mathrm{R} \\
\text { Square } \\
\text { Change }\end{array}$ & $\begin{array}{c}\mathrm{F} \\
\text { Change }\end{array}$ & $\begin{array}{c}\mathrm{df} \\
1\end{array}$ & df2 & $\begin{array}{c}\text { Sig. } \\
\text { F } \\
\text { Change }\end{array}$ & \\
\hline 1 &, $952^{\mathrm{a}}$ & 906 & ,952 & 08844 & ,096 & 562,028 & 1 & 58 & ,000 & 2,000 \\
\hline
\end{tabular}

Keterangan :

a. predictors: (Constant), Ln_Hk

b. Dependent Variable: Ln_Hp

$\mathrm{N}=60 ; \mathrm{K}=2 ; d l=1,154 ; d u=1,651$

Critical Values for Durbin Watson test : 5\% Significant Level.

Berdasarkan hasil transformasi data di atas maka diperoleh nilai durbin Watson sebesar 2,000 dengan tingkat keyakinan adalah 95\%. Uji regresi variabel independen dan jumlah pengamatan sebanyak 60 (Tabel 3) memperlihatkan nilai $d l=1,514 ; d u=1,651$. Nilai $d$ yang didapat sebesar 2,000 lebih besar dari nilai $d u$ sebesar 1,651 menunjukkan tidak terjadi autokorelasi positif, artinya menerima Hipotesis pertama $\left(\mathrm{H}_{0}\right)$.

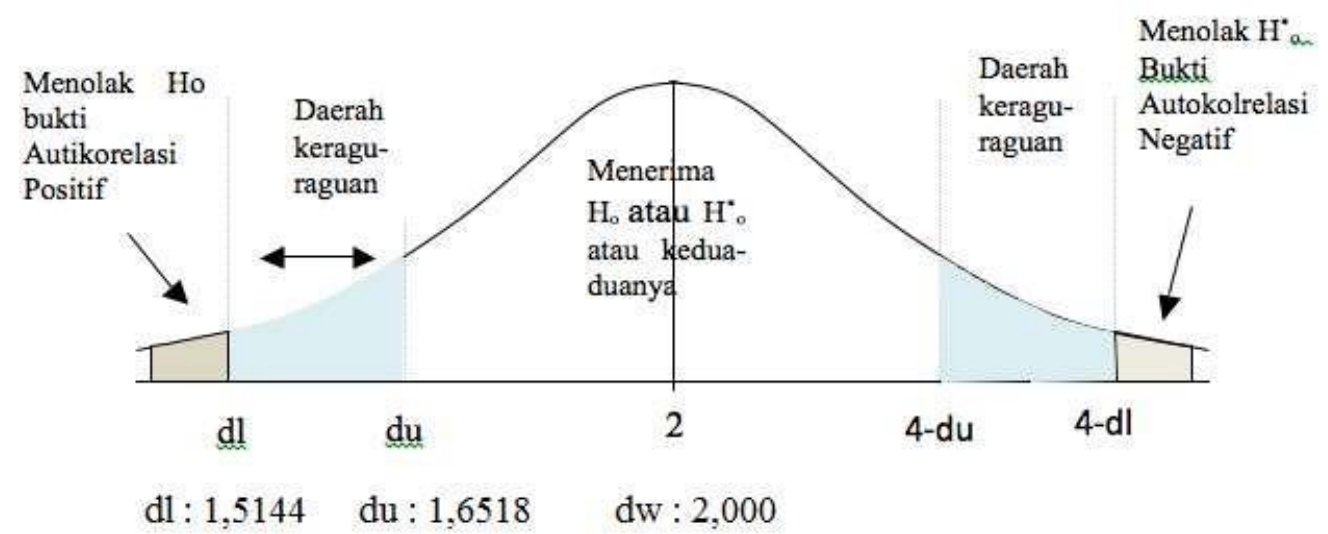




\section{Analisis Elastisitas Transmisi Harga}

Berdasarkan hasil analisis regresi linier sederhana data dilakukan transformasi proses penghitungannya menggunakan aplikasi SPSS versi 21 diperoleh nilai koefisien dan elastisitas transmisi harga pada Tabel 4.

Tabel 4. Nilai Analisis Elastisitas Transmisi Harga

\begin{tabular}{|c|c|c|c|c|c|c|c|c|}
\hline \multicolumn{9}{|c|}{ Coefficients $^{\mathbf{a}}$} \\
\hline & \multirow[t]{2}{*}{ Model } & & $\begin{array}{l}\text { ardized } \\
\text { cients }\end{array}$ & \multirow{2}{*}{$\begin{array}{c}\text { Standardized } \\
\text { Coefficients } \\
\text { Beta }\end{array}$} & \multirow[t]{2}{*}{$\mathrm{t}$} & \multirow[t]{2}{*}{ Sig. } & \multicolumn{2}{|c|}{ Collinearity Statistics } \\
\hline & & B & Std. Error & & & & Tolerance & VIF \\
\hline \multirow{2}{*}{1} & (Constant) & ,006 & ,026 & & ,239 & 812 & & \\
\hline & Ln_Hk & ,944 & ,040 & ,952 & 23,707 & ,000 & 1,000 & 1,000 \\
\hline
\end{tabular}

Keterangan :

c. Predictors: (Constant), Ln_Hk

d. Dependent Variable: Ln_Hp

$\mathrm{N}=60 ; \mathrm{K}=2 ; d l=1,154 ; d u=1,651$

Critical Values for Durbin Watson test : $5 \%$ Significant Level.

Nilai elastisitas transmisi harga jagung berasal dari B pada Tabel 4 sebesar 0,944 bahwa nilai Et $<1$, artinya perubahan harga sebesar $1 \%$ di tingkat konsumen akan mengakibatkan perubahan harga di tingkat produsen sebesar $0,944 \%$.

$$
\begin{aligned}
& \mathrm{L}_{n} \mathrm{Pf}=\mathrm{L} \beta 0+\beta 1 \mathrm{LnPr}+\mathrm{e} \\
& \mathrm{L}_{n} \mathrm{P}_{\mathrm{f}}=0,006+0,944 \mathrm{~L}_{n} \mathrm{P}_{\mathrm{r}}+ \\
& \mathrm{e}
\end{aligned}
$$

Nilai konstanta $\left(b_{0}\right)$ adalah setiap nilai konstanta yang dihasilkan baik nilai konstanta negatif () maupun positif (+) akan selalu mempengaruhi harga di tingkat produsen maupun konsumen, nilai konstanta $\left(b_{0}\right)$ yang diperoleh adalah 0,006 (positif). Jika nilai konstanta bernilai negatif (-) artinya harga di tingkat produsen berada di bawah nol karena tidak ada permintaan dari konsumen atau bagian harga yang diterima produsen rendah karena nilai konstanta bernilai positif $(+)$.

Berdasarkan nilai koefisien determinasi $\left(\mathrm{R}^{2}\right)$ yang diperoleh sebesar 0,906 , yaitu nilai koefisien determinasi $\left(\mathrm{R}^{2}\right)$ semakin mendekati satu. Besarnya koefisien determinasi $\left(\mathrm{R}^{2}\right)$ suatu persamaan regresi, maka besar pula pengaruh variabel independen (harga konsumen) terhadap variabel dependen (harga produsen) yang berarti semakin besar kemampuan model yang dihasilkan dalam menjelaskan perubahan nisbi variabel dependen, artinya koefisien determinasi dipengaruhi oleh harga konsumen terhadap harga produsen yaitu 90,60 \% dipengaruhi oleh harga konsumen untuk menjelaskan perubahan nisbi harga produsen, 9,40\% variabel lainnya yang tidak mempengaruhi. Dapat dilihat pada Tabel 5. 
Tabel 5. Model Summary (nilai $\mathrm{R}^{2}$ )

\begin{tabular}{|c|c|c|c|c|c|c|c|c|c|c|}
\hline \multirow[b]{3}{*}{ Model } & \multirow[b]{3}{*}{$\mathrm{R}$} & \multirow[b]{3}{*}{$\begin{array}{c}\mathrm{R} \\
\text { Square }\end{array}$} & \multicolumn{7}{|c|}{ Model Summaryb } & \multirow[b]{3}{*}{$\begin{array}{l}\text { Durbin } \\
\text { Watson }\end{array}$} \\
\hline & & & & $\begin{array}{l}\text { Std. } \\
\end{array}$ & & Chan & Sta & & & \\
\hline & & & $\begin{array}{c}\text { Adjusted } \\
\text { R } \\
\text { Square }\end{array}$ & $\begin{array}{l}\text { Error of } \\
\text { the } \\
\text { Estimate }\end{array}$ & $\begin{array}{c}\mathrm{R} \\
\text { Square } \\
\text { Change }\end{array}$ & $\begin{array}{c}\mathrm{F} \\
\text { Change }\end{array}$ & $\begin{array}{c}\mathrm{df} \\
1\end{array}$ & df 2 & $\begin{array}{c}\text { Sig. } \\
\text { F } \\
\text { Change }\end{array}$ & \\
\hline 1 & ,952a & 906 & ,952 & ,08844 & ,096 & 562,028 & 1 & 58 & ,000 & 2,000 \\
\hline
\end{tabular}

Keterangan :

a. predictors: (Constant), Ln_H

b. Dependent Variable: Ln_Hp

Analisis elastisitas harga merupakan suatu persamaan untuk mengukur tingkat efisien pemasaran suatu komoditas pertanian dalam hal ini adalah efisien pemasaran jagung di Kabupaten Indramayu. Efisiensi pemasaran jagung dapat diketahui menggunakan analisis elastisitas transmisi harga. Setelah dilakukan perhitungan tingkat elastisitas transmisi harga jagung menggunakan analisis regresi kuadratik dengan data yang ditransformasikan ke dalam bentuk linier. Penghitungan ini menggunakan aplikasi SPSS versi 21. Setelah melakukan analisis maka diketahui nilai elastisitas transmisi harga sebesar 0,481 maka Et $<1$ tetapi di dalam persamaan regresi terjadi masalah autokorelasi sehingga perlu dilakukan transformasi data menggunakan teknik Theil Nagar dan diperoleh nilai elastisitas transmisi harga sebesar 0,944 maka nilai Et $<1$ yang berarti pemasaran jagung di Kabupaten Indramayu tidak efisien. Berdasarkan elastisitas transmisi jagung 0,944 artinya kenaikan harga sebesar 1\% di tingkat konsumen dan mengakibatkan penurunan harga sebesar $0.944 \%$ di tingkat produsen.

Hal ini dikarenakan di dalam pemasaran jagung, petani umumnya menjual kepada pedagang yang ada di desa atau pedagang dari luar desa yang datang ke rumah-rumah petani. Tetapi untuk petani yang produksi jagungnya cukup besar dan tidak ada pedagang desa di daerahnya, maka mereka langsung menjualnya kepada tengkulak. Selain itu rendahnya posisi tawar petani disebabkan terjadinya over supply yang selalu terjadi saat panen raya sehingga mengakibatkan rendahnya harga yang diterima petani (Bimantara, 2018

\section{IV.Kesimpulan \\ Kesimpulan}

Berdasarkan hasil dari penelitian efisiensi pemasaran jagung tongkol di Kabupaten Indramayu maka dapat disimpukan sebagai berikut : Besarnya elastisitas transmisi harga jagung tongkol di Kabupaten Indramayu adalah 0,944. Pemasaran jagung tongkol tidak efisien di Kabupaten Indramayu.

\section{Saran}

Berdasarkan kesimpulan penelitian ini maka ada beberapa saran yang dapat disampaikan, yaitu : Dukungan pemerintah sangat diperlukan dalam upaya peningkatan produksi jagung tongkol agar tidak impor dari luar daerah Indramayu. Perlunya penguatan kelembagaan petani seperti kelompok tani, gabungan kelompok tani dan koperasi tani agar para petani memiliki bargaining power terhadap tengkulak, lembaga terkait dan lembaga lainnya guna mengatasi permasalahan petani untuk mendapatkan akses informasi harga atau informasi pasar agar pemasaran produk pertanian efisien khususnya untuk komoditas jagung tongkol di Kabupaten Indramayu.

\section{Ucapan Terima Kasih}


Ucapan Terimaksih saya ucapkan kepada Fakultas Pertanian dan LPPM UNWIR yang telah membantu dalam penelitian ini Sehingga penelitiian ini dapat terlaksana dengan baik.

\section{DAFTAR PUSTAKA}

Abdi, Ibrahim. 2018. Analisis Pemasaran Jagung (Zea mays L. ) (Studi Kasus: Desa Ambarisan, Kecamatan Sidamanik, Kabupaten Simalungun). Skripsi. Fakultas Pertanian, Universitas Muhammadiyah Sumatra Utara [Internet]. [diunduh 2021 januari 21]; Medan. Tersedia pada: http://repositori.umsu.ac.id/xmliu/handle/123456789/876

Azria. 2017. Strategi Pemasaran Jagung di Kecamatan Palolo Kabupaten Sigi. e-Jurnal Mitra Sains [Internet]. [diunduh 2021 januari 21]; 5 (3):11-27: Palu.

Badan Pusat Statistik Kabupaten Indramayu. 2014. Indramayu Dalam Angka Tahun 2014. Badan Pusat Statistik Kabupaten Indramayu [Internet]. [diunduh 2021 januari 21]; Indramayu. Tersedia pada http://bps.go.id.

Badan Pusat Statistik Kabupaten Indramayu. 2015. Indramayu Dalam Angka Tahun 2015. Badan Pusat Statistik Kabupaten Indramayu [Internet]. [diunduh 2021 januari 21]; Indramayu. Tersedia pada http://bps.go.id.

Badan Pusat Statistik Kabupaten Indramayu. 2016. Indramayu Dalam Angka Tahun 2016. Badan Pusat Statistik Kabupaten Indramayu [Internet]. [diunduh 2021 januari 22]; Indramayu. Tersedia pada http://bps.go.id.

Badan Pusat Statistik Kabupaten Indramayu. 2017. Indramayu Dalam Angka Tahun 2017. Badan Pusat Statistik Kabupaten Indramayu [Internet]. [diunduh 2021 januari 22]; Indramayu. Tersedia pada http://bps.go.id.

Badan Pusat Statistik Kabupaten Indramayu. 2018. Indramayu Dalam Angka Tahun 2018. Badan Pusat Statistik Kabupaten Indramayu [Internet]. [diunduh 2021 januari 22]; Indramayu. Tersedia pada http://bps.go.id.

Bimantara, L. 2018. Analisis Efisiensi Pemasaran Pisang Ambon di Kabupaten Indramayu Tahun 2013-2016. Indramayu (ID): Fakultas Pertanian, Universitas Wiralodra.

Gujarati, D.N. 2012. Dasar-Dasar Ekonometrika (Alih Bahasa: Mangunsong) Jakarta (ID): Salemba Empat.

Mubyarto. 1989. Pengantar Ekonomi Pertanian. Jakarta (ID): LPES.

Purwanto, H. 2009. Teknologi Pengolahan Hasil Pertanian. Jurnal Ilmu-ilmu Pertanian, MEDIARGO [Internet]. [diunduh 2021 januari 25]; 5 (1): 15-19: Jawa Tengah. Tersedia pada Fakultas Teknik Universitas Wahid Hasyim Semarang.

Restiana. 2010. Pola Distribusi Dan Efisiensi Pemasaran Jagung Di Kabupaten Lampung Selatan. Fakultas Pertanian, Universitas Lampung [Internet]. [diunduh 2021 januari 24]: Bandar Lampung.

Sukirno, Sadono. 1998. Pengantar Teori Makro Ekonomi. Jakarta (ID): PT Raja Grafindo Persada. 
Sondakh, J., Rauf, A,W., Rembang, J, H, W dan Sudarti. 2016. Analisis Produksi dan Rantai Pemasaran Jagung di Kabupaten Minahasa Selatan Provinsi Sulawesi Utara. Jurnal Pengkajian dan Pengembangan Teknologi Pertanian [Internet]. [diunduh 2021 januari 23] ; 19 (3): 213-226. Manado.

Widiastuti, N dan Harisudin, M. 2013. Saluran dan Marjin Pemasaran Jagung di Kabupaten Grobogan. SEPA (1829-9946) [internet]. [diunduh 2021 januari 22]; 9 (2): 231 - 240: Surakarta. Tersedia pada Universitas Sebelas Maret.

Zulfahmi, M, G, A. 2012. Laporan Analisis Kebutuhan Air, Schedulling Irigasi dan Perancangan Metode Irigasi Tanaman Jagung di Desa Najum, Kecamatan Sumberpucung. Universitas Brawijaya. Fakultas Pertanian [internet]. [diunduh 2021 januari 25]: Malang. 